\title{
What Determines Export Participation of Private Domestic Manufacturing SMEs in Vietnam?
}

\author{
Nguyen Trong Co ${ }^{1}$, Tran Duc Hiep ${ }^{2} \&$ Vu Van Huong ${ }^{1}$ \\ ${ }^{1}$ Academy of Finance, Hanoi, Vietnam \\ ${ }^{2}$ University of Economics and Business, Vietnam National University, Hanoi, Vietnam \\ Correspondence: Vu Van Huong, Academy of Finance, Hanoi, Vietnam. E-mail: huongvu@waikato.ac.nz
}

Received: January 6, 2014 Accepted: March 9, 2015 Online Published: May 15, 2015

doi:10.5539/ass.v11n15p70 URL: http://dx.doi.org/10.5539/ass.v11n15p70

\begin{abstract}
This study provides for the new evidence of factors determining export participation of private manufacturing SMEs in Vietnam. Using a recent national survey in 2011 about private manufacturing SMEs, we find that while more years in business does not affect the probability of firm exporting, firm with smaller scale have a lower likelihood of exporting. The results also indicate that innovation has a positive effect on exporting probability of firms implying that encouragement of innovative activities play an important role in promoting exporting participation of private domestic SMEs.
\end{abstract}

Keywords: export, manufacturing, private, SMEs, Vietnam

\section{Introduction}

Since the introduction of the renovation policy (Đổi Mới) in 1986, Vietnam has pursued a market-oriented economy. The country has witnessed great success from the implementation of various reform measures, which have focused mainly on the encouragement of foreign direct investment and the promotion of export-oriented industries. The economy achieved an annual average GDP growth rate of 6.8\% during the 1986-2009 period (Le, 2010). The GDP per capita growth of Vietnam is always higher than compared to the corresponding figure of nations with low and middle income during the period 1988-2006 (Markussen et al., 2012). In addition, there has been a significant improvement in the share of GDP by different sectors. A steady decline in the agricultural sector share from $40.6 \%$ in 1986 to $18 \%$ was recorded in 2008 , while the share of the industry and service sectors increased significantly (from $28.4 \%$ to $42 \%$ and from $31 \%$ to $44 \%$ respectively in the same period). ${ }^{1}$ Furthermore, the poverty rate in Vietnam fell from nearly 60\% in the early 1990s to 20.7\% in 2010 (World Bank, 2012).

Exports are one factor that contributed greatly to Vietnam's economic success. The average annual export growth rate was 21.2\%, almost doubling the GDP growth rate in the 1986-2007 period. Export values increased nearly sixty fold from US\$789 million in 1986 to US\$48.6 billion in 2007 and the export share of total trade increased steadily from $35.7 \%$ in $1986-1990$ to $45 \%$ in $2001-2007$. The most impressive figure reached was around US\$62.7 billion in 2008, the highest export turnover ever seen in Vietnam. ${ }^{2}$

Also, the Vietnamese non-state sector, especially small and medium sized enterprises (SMEs), constitutes another vital factor contributing to this success. First, SMEs play an important role in employment generation. In 2005, for example, 2.5 million jobs were created by SMEs (Trung, Tung, Dong, \& Duong, 2009). SMEs are also regarded as the main engine for alleviating poverty, especially in rural areas (Kokko \& Sjöholm, 2005). Furthermore, the Vietnamese economy is numerically dominated by SMEs, with $96 \%$ of the total number of enterprises contributing nearly 40\% of GDP and 32\% of total investment in 2006 (Hung, 2007).

However, the contribution of SMEs to export growth is still modest in comparison with neighbouring countries. Only a small percentage of Vietnamese SMEs, nearly 20\%, was engaged in exports, while China, India, Taiwan, and South Korea witnessed significant contributions of SMEs to exports, with approximately $60 \%, 38 \%, 56 \%$, and $40 \%$ respectively in the 1990s (United Nations Conference on Trade and Development, 2003, as cited in Tambunan (2007)). Furthermore, considering only domestic non-state manufacturing SMEs, recent surveys reveal that export participation ranged from 3\% to nearly 6\% in the period 2002-2009 (Coung, Rand, Silva, Tam, \& Tarp, 2010; Cuong et al., 2010; Kokko \& Sjöholm, 2005; Rand \& Tarp, 2006). 
In a rapidly changing international market environment and especially now that Vietnam is a member of the World Trade Organization (WTO), there are main several reasons for SMEs to engage in exporting market. The most obvious reason is the opportunity for firms to expand in scale and markets (Van Biesebroeck, 2005). Exporting allows firms to enter new markets, which can lead to larger volumes of sales and production, and this may generate revenue growth and higher profit. In addition, the presence of SMEs in export markets can lead to an increase in market strength and ensure a higher survival probability than for non-exporters (e.g., Bernard \& Jensen, 1999; Esteve-Pérez, Mánez-Castillejo, \& Sanchis-Llopis, 2008).

Furthermore, export participation helps enterprises improve their financial health compared to non-exporters (Greenaway, Guariglia, \& Kneller, 2007). Another reason for participating in the export market is learning by exporting. New knowledge, exposure to intense competition, and understanding international markets help firms enhance their productivity when exporting (e.g., Baldwin \& Gu, 2003; Park, Yang, Shi, \& Jiang, 2010). Without such participation, these firms may become outdated and continue to use inappropriate marketing or management strategies, which may result in inefficiency and threaten their long term prospects.

In the Vietnamese context, the importance of a firm's participation in the export market has been recognized in previous studies. For example, Kokko and Sjöholm (2005) show that the Vietnamese domestic market is small. Thus, participating in the export market may promote the growth of enterprises. In addition, export participation helps firms improve their productivity, and increase revenue (Hiep \& Ohta, 2009). Some studies also indicate that export participation and growth help create and expand employment (e.g., Jenkins, 2004; Kien \& Heo, 2009).

Despite the studies mentioned above, questions still remain about export performance, especially for non-state domestic manufacturing SMEs. First, whereas export participation may greatly benefit firms, it is less clear why many domestic non-state manufacturing SMEs have not taken advantage of opportunities to participate in exporting. What challenges and barriers hinder them from participating in export activities? Our study will contribute to the literature by providing the new evidence of factors determining export participation of domestic private SMEs in Vietnam.

The paper includes three parts except for introduction. Section 2 presents data sources and methodology, while the empirical results are discussed in the part 3 . The final section summarises the main findings and presents several policy implications.

\section{Model Specification and Data}

\subsection{The Data}

This study will use a data set drawn from a recent survey of private small medium sized enterprises in Vietnam in 2011. This data are conducted by the Institute of Labour Science and Social Affairs (ILSSA) in cooperation with the Department of Economics, Copenhagen University, Denmark.

There are several advantages of the dataset. First, dataset are surveyed from 10 provinces but covered for the North, Centre and South regions of Vietnam (Note 3). In addition, the information such as the export status of firms, firm size as measured by the number of labourers, firm age, types of ownership, wages, the main manufacturing sectors and innovative activities of firms are available in the dataset. Hence, this makes possible an exercise of considering the determinants of export participation of manufacturing SMEs. The statistical descriptions of main variables in the model are displayed as Table 1 below.

Table 1. The definition of variables in the model of export participation

\begin{tabular}{|c|c|c|c|c|}
\hline Variables & Definitions and measurement & Obs & Mean & Sd \\
\hline \multicolumn{5}{|l|}{ Dependent variables } \\
\hline Export participation & 1 if firm participate in exporting market; 0 otherwise(dummy variable) & 2429 & 0.058 & 0.235 \\
\hline \multicolumn{5}{|l|}{$\begin{array}{l}\text { Explanatory } \\
\text { variables }\end{array}$} \\
\hline LP & $\begin{array}{l}\text { Labour Productivity calculated by value added per total employees } \\
\text { (number) }\end{array}$ & 2429 & 17.69 & 24.85 \\
\hline Firm size & Total employment (number) & 2429 & 15.28 & 28.53 \\
\hline Firm age & The number of years in business (established time is foundation year) & 2429 & 13.51 & 9.46 \\
\hline
\end{tabular}




\begin{tabular}{|c|c|c|c|c|}
\hline Variables & Definitions and measurement & Obs & Mean & Sd \\
\hline & (number) & & & \\
\hline Average real wage & The ratio between total wage and total employees (ratio) & 2429 & 5.53 & 4.77 \\
\hline Innovation & $\begin{array}{l}1 \text { if firms introduced new products, had major improvements in existing } \\
\text { products, or introduced new production processes or technology, } 0 \\
\text { otherwise (dummy variable) }\end{array}$ & 2429 & 0.44 & 0.496 \\
\hline High tech sectors & 1 if enterprises in tech sectors, 0 otherwise (dummy variable) & 2429 & 0.12 & 0.32 \\
\hline Medium tech sectors & 1 if enterprises in medium tech sectors, 0 otherwise (dummy variable) & 2429 & 0.30 & 0.46 \\
\hline Low tech sectors & 1 if enterprises in low tech sectors, 0 otherwise (dummy variable) & 2429 & 0.578 & 0.49 \\
\hline Household ownership & 1 if enterprises have household ownerships, 0 otherwise (dummy variable) & 2429 & 0.653 & 0.475 \\
\hline Private ownership & 1 if enterprises have private ownerships, 0 otherwise (dummy variable) & 2429 & 0.079 & 0.269 \\
\hline Collective ownership & $\begin{array}{l}1 \text { if enterprises have partnership or cooperative ownerships, } 0 \text { otherwise } \\
\text { (dummy variable) }\end{array}$ & 2429 & 0.026 & 0.16 \\
\hline $\begin{array}{l}\text { Limited liability } \\
\text { ownership }\end{array}$ & $\begin{array}{l}1 \text { if enterprises have limited liability ownerships, } 0 \text { otherwise (dummy } \\
\text { variable) }\end{array}$ & 2429 & 0.203 & 0.402 \\
\hline Join-stock ownership & 1 if enterprises have joint-stock ownerships, 0 otherwise (dummy variable) & 2429 & 0.037 & 0.189 \\
\hline Hanoi & 1 if firms locate in Ha Noi, 0 otherwise (dummy variable) & 2429 & 0.251 & 0.43 \\
\hline Phutho & 1 if firms locate in Phu Tho, 0 otherwise (dummy variable) & 2429 & 0.103 & 0.30 \\
\hline Haiphong & 1 if firms locate in Hai Phong, 0 otherwise (dummy variable) & 2429 & 0.082 & 0.27 \\
\hline Nghe An & 1 if firms locate in Nghe An, 0 otherwise (dummy variable) & 2429 & 0.142 & 0.349 \\
\hline Quang Nam & 1 if firms locate in Quang Nam, 0 otherwise (dummy variable) & 2429 & 0.066 & 0.248 \\
\hline Khanh Hoa & 1 if firms locate in Khanh Hoa, 0 otherwise (dummy variable) & 2429 & 0.039 & 0.195 \\
\hline Lam Dong & 1 if firms locate in Lam Dong, 0 otherwise (dummy variable) & 2429 & 0.032 & 0.176 \\
\hline Ho Chi Minh & 1 if firms locate in Ho Chi Minh, 0 otherwise (dummy variable) & 2429 & 0.23 & 0.42 \\
\hline Long An & 1 if firms locate in Long An, 0 otherwise (dummy variable) & 2429 & 0.051 & 0.22 \\
\hline
\end{tabular}

\subsection{Model Specification}

In order to quantify factors determining export participation of firms, micro-econometric approaches will be used. These approaches would help reveal marginal effects of any explanatory covariates of interests in a given estimation equation. Export participation is measured as a binary variable. Therefore, a Probit or Logit might be used. However, Probit model is employed in this study because the cumulative probability distribution function of Logit is less asymptotic between zero and one than Probit (Wooldridge, 2002). Specifically, the model is specified as below:

$$
P\left(\text { Export participation }_{i}=1 \mid x\right)=G\left(\beta_{0}+\beta_{1^{*}} X_{i}+\beta_{2^{*}} \text { Innovation }_{i}+\beta_{2^{*}} \text { Location }_{i}+\beta_{3^{*}} \text { Sectors }_{i}\right)
$$

According to previous studies (e.g., Aw, Roberts, \& Winston, 2007; Roper, Love, \& Hagon, 2006; Wagner, 2001), Vector of $X_{i}$ includes the firm productivity based on the findings firms with higher productivity has a higher export probability. In addition, traditional firm characteristic variables such as firm age and firm size are included in the vector $\mathrm{X}$ as guided by the literature.

This study also controls for innovative activities in the model on the basis of findings that there is a close relationship between innovation and the probability of exporting of firms (e.g., Huang, Zhang, Zhao, \& Varum, 2008).

Furthermore, the geographical location of firms can have an effect on export participation. Hence, nine provinces in the dataset were included in the model to capture fixed effects of location. In addition to these considerations, certain industry characteristics may have a variety of effects on the exporting probability of firm. Consequently, following classification of technological level by Vu, Lim, Holmes, and Doan (2013), the different sectors in which enterprises operate were captured by using dummy variables according to various sectors' technology levels. 


\section{Empirical Discussion}

Table 2 reports the estimation results from the Probit model in the form of coefficients and marginal effects. As can be seen in Table 2, there are many estimated coefficients of independent covariates being statistically significant, with their signs as expected. First, productivity, as measured by labour productivity, has a positive but insignificant influence on firm exporting probability. However, an insignificant impact can stem from the fact that labour productivity just is a part of productivity picture. The above results also indicate that the quality of employment, as measured by average wage, does not improve the likelihood of engagement of Vietnamese SMEs in exporting market.

Table 2. Determinants of export participation

\begin{tabular}{ccccc}
\hline VARIABLES & Coefficients & SEs & Marginal Effects & SEs \\
\cline { 2 - 5 } & $(1)$ & $(2)$ & $(3)$ & $(4)$ \\
\hline Firm size & $0.0118^{* *}$ & $(0.001)$ & $0.0006^{* *}$ & $(0.000)$ \\
Productivity & 0.0004 & $(0.001)$ & 0.0000 & $(0.000)$ \\
Firm age & 0.0023 & $(0.006)$ & 0.0001 & $(0.005)$ \\
Innovation & $0.1757+$ & $(0.104)$ & $0.0098+$ & $(0.001)$ \\
Average wage & 0.0092 & $(0.011)$ & 0.0005 & $(0.005)$ \\
High tech sectors & $-0.3535^{*}$ & $(0.155)$ & $-0.0148^{* *}$ & $(0.005)$ \\
Medium tech sectors & $-0.5834^{* *}$ & $(0.128)$ & $-0.0261^{* *}$ & $(0.022)$ \\
Private ownership & $0.5301^{* *}$ & $(0.183)$ & $0.0448^{*}$ & $(0.038)$ \\
Collective ownership & $0.5909^{*}$ & $(0.270)$ & 0.0553 & $(0.017)$ \\
Limited liability ownership & $0.7183^{* *}$ & $(0.143)$ & $0.0609^{* *}$ & $(0.022)$ \\
Join-stock ownership & 0.2843 & $(0.254)$ & 0.0200 & $(0.007)$ \\
Phutho & -0.2998 & $(0.207)$ & $-0.0129+$ & $(0.005)$ \\
Haiphong & $-0.5640^{* *}$ & $(0.211)$ & $-0.0195 * *$ & $(0.005)$ \\
Nghe An & $-0.8692^{* *}$ & $(0.268)$ & $-0.0274^{* *}$ & $(0.005)$ \\
Quang Nam & $-0.7146^{*}$ & $(0.336)$ & $-0.0217^{* *}$ & $(0.006)$ \\
Khanh Hoa & $-0.5131+$ & $(0.303)$ & $-0.0176^{* *}$ & $(0.011)$ \\
Lam Dong & -0.1921 & $(0.294)$ & -0.0087 & $(0.006)$ \\
Ho Chi Minh & -0.0794 & $(0.122)$ & -0.0041 & $(0.006)$ \\
Long An & $-0.5263+$ & $(0.308)$ & $-0.0181 * *$ & 2,429 \\
Observations & 2,429 & &
\end{tabular}

Notes: $(+),(*)$ and $(* *)$ denote significance at $10 \%, 5 \%$ and $1 \%$ respectively. The estimated coefficients are presented in column (1), while column (3) reports marginal effects of estimated coefficients are repo. The base category of ownership is household ownership, while Hanoi is the base category of location dummies.

Moving on to the firm characteristics variable, as reported by Table 2, regression results of the determinants of export participation reveal that innovation has a positive impact on the exporting engagement of SMEs. More specifically, firms with innovation activities such as the introduction of new products, and application new technology in production process gain nearly a percent higher likelihood of participating into exporting market than their counterparts without these activities. The findings indicate that innovation is one of the decisive factors in participating in exporting probability of Vietnamese SMEs.

Regarding the role of types of ownership in the exporting decision of firms, firms with join-stock, co-operative or limited ownership are more likely to participate into exporting market than household enterprises. This finding is in line with a recent study by Cuong et al. (2010). The result is explained partly by the fact that informality and operations in small-scale are main characteristics of household enterprises (Cuong et al., 2010). As a result, such characteristics will be impediments for enterprises wanting to become exporters.

With respect to other firm characteristics, more years in business do not constitute a factor significantly influencing the firms' likelihood of exporting, but it is much different if considering the role of firm size in export activities. Specifically, a per cent increase in firm size will lead to a 0.6 per cent increase in the firms' likelihood of entering the export market, all else being equal. This finding seems to reflect the fact that Vietnamese SMEs export labour-intensive products.

Considering the effect of locations on the decision to export, we find that SMEs that locate in different provinces show various probabilities of exporting. Specifically, SMEs operating in Hanoi often has a higher probability of 
export than firms locating in other provinces. This may be because firms in the capital often has advantages such as good infrastructures and networks, and these may help firms overcome entry costs more easily than their counterparts in other regions when engaging into exporting markets.

Finally, Table 2 also reports the role of sector characteristics for exporting probability of SMEs. As expected, firms belong to medium and high sectors are less likely to participate into exporting market than their counterparts operating in low technology sectors. The finding is consistent with the result of a recent report released by Ministry of Industry and Trade of Vietnam and United Nations Industrial Development Organisation (2011). Their report reveals that the majority of Vietnamese exported products stem from low technology industries and goods in medium and high technology sectors have little exporting probability.

\section{Summary and Conclusion}

This paper examines what determines export participation of manufacturing SMES in Vietnam. Using a micro-econometric approach with the recent dataset for non-state manufacturing SMEs, this paper shows the findings consistent with the prior research and provides new evidence from Vietnam. For instance, enterprises with more years in business do not have a significant linkage with SMEs' the probability of export impact on export probability. However, firms have larger size, the higher their probability of enterprises participates in the export market. Moreover, while employment quality as measured by average wage has little effect export participation of firms, enterprises operating in low tech sectors have a higher likelihood in participating into export market than their counterparts in medium and high tech sectors. Finally, private SMEs will export more if they have more innovative activities. This suggests that supporting activities for improvement in innovation are important for helping firms increase the probability of exporting.

\section{Acknowledgments}

The authors thank Vietnam National University and VNU University of Economics and Business for funding this research. The author also thanks colleagues for helpful comments on earlier versions of this paper.

\section{References}

Aw, B. Y., Roberts, M. J., \& Winston, T. (2007). Export market participation, investments in R\&D and worker training, and the evolution of firm productivity. The World Economy, 30(1), 83-104. http://dx.doi.org/10.1111/j.1467-9701.2007.00873.x

Baldwin, J. R., \& Gu, W. (2003). Export-market participation and productivity performance in Canadian manufacturing. Canadian Journal of Economics/Revue Canadienne D'économique, 36(3), 634-657. http://dx.doi.org/10.1111/1540-5982.t01-2-00006

Bernard, A. B., \& Jensen, J. B. (1999). Exceptional exporter performance: cause, effect, or both? Journal of International Economics, 47(1), 1-25. http://dx.doi.org/10.1016/S0022-1996(98)00027-0

Coung, T. T., Rand, J., Silva, P., Tam, N. T., \& Tarp, F. (2010). Dac diem moi truong kinh doanh o Vietnam / Characteristics of the Vietnamese Business Environment: Evidence from a SME survey in 2009. Hanoi, VietNam: CIEM.

Cuong, T. T., Rand, J., Torm, N., Chieu, T. D., McCoy, S., \& Bjerge, B. (2010). Dac diem moi truong kinh doanh o Vietnam / Characteristics of the Vietnamese Business Environment: Evidence from a SME survey in 2009. Hanoi, VietNam: CIEM.

Esteve-Pérez, S., Mánez-Castillejo, J. A., \& Sanchis-Llopis, J. A. (2008). Does a "survival-by-exporting" effect for SMEs exist? Empirica, 35(1), 81-104. http://dx.doi.org/10.1007/s10663-007-9052-1

Greenaway, D., Guariglia, A., \& Kneller, R. (2007). Financial factors and exporting decisions. Journal of International Economics, 73(2), 377-395. http://dx.doi.org/10.1016/j.jinteco.2007.04.002

Hiep, N., \& Ohta, H. (2009). Superiority of exporters and the causality between exporting and firm characteristics in Vietnam RIEB (Research Institute for Economics \& Business Administration).

Huang, C., Zhang, M., Zhao, Y., \& Varum, C. A. (2008). Determinants of exports in China: A microeconometric analysis. The European Journal of Development Research, 20(2), 299-317. http://dx.doi.org/10.1080/ 09578810802060793

Hung, H. S. (2007). Strengthening supporting industries in Vietnam: Linking Vietnamese SMEs into global value chains. Retrieved from http://old.asean.or.jp/invest/archive/speech/fy07\%20JAIF\%20Seminar/21_Mr.\%20 Ho.pdf

Jenkins, R. (2004). Vietnam in the global economy: Trade, employment and poverty. Journal of International 
Development, 16(1), 13-28. http://dx.doi.org/ 10.1002/jid.1060

Kien, T. N., \& Heo, Y. (2009). Impacts of Trade Liberalization on Employment in Vietnam: A System Generalized Method of Moments Estimation. The Developing Economies, 47(1), 81-103. http://dx.doi.org/10.1111/j.1746-1049.2009.00077.x

Kokko, A., \& Sjöholm, F. (2005). The internationalization of Vietnamese small and medium-sized enterprises. Asian Economic Papers, 4(1), 152-177. http://dx.doi.org/10.1162/asep.2005.4.1.152

Le, C. L. V. (2010). Technical efficiency performance of Vietnamese manufacturing small and medium enterprises (Unpublished doctoral dissertation). School of Economics-Faculty of Commerce, University of Wollongong, NSW, Australia.

Markussen, T., Newman, C., Khai, L. D., Diem, H. X., Nhan, T. T. T., Thanh, N. Q., . . Tarp, F. (2012). Dac diem kinh te nong thon Vietnam ket qua dieu tra ho gia dinh nam 2012 tai 12 tinh /Characteristics of the Vietnamese rural economy evidence from a 2012 rural household survey in 12 provinces of Vietnam. Hanoi, Vietnam: Nha Xuat Ban Lao Dong Xa Hoi.

Ministry of Industry and Trade of Vietnam, [MITV], \& United Nations Industrial Development Organisation, [UNIDO]. (2011). Vietnam industrial competitiveness report (pp. 1-20).

Park, A., Yang, D., Shi, X., \& Jiang, Y. (2010). Exporting and firm performance: Chinese exporters and the Asian financial crisis. The Review of Economics and Statistics, 92(4), 822-842. http://dx.doi.org/10.1162/ REST_a_00033

Rand, J., \& Tarp, F. (2006). Dac diem moi truong kinh doanh o Vietnam / Characteristics of the Vietnamese Business Environment: Evidence from a SME survey in 2005. Hanoi, VietNam: CIEM.

Roper, S., Love, J. H., \& Hagon, D. A. (2006). The determinants of export performance: Evidence for manufacturing plants in Ireland and Northern Ireland. Scottish Journal of Political Economy, 53(5), 586-615. http://dx.doi.org/10.1111/j.1467-9485.2006.00396.x

Tambunan, T. (2007). Trade and investment liberalization and the development of small and medium-sized enterprises: A perspective from Indonesia. Asia-Pacific Trade and Investment Review, 3(2), 135-146.

Trung, T. Q., Tung, N. T., Dong, T. D., \& Duong, P. H. (2009). Performance of export-oriented small and medium-sized manufacturing enterprises in Viet Nam. Asia-Pacific Trade and Investment Review 2008, 4, 83.

Van Biesebroeck, J. (2005). Exporting raises productivity in sub-Saharan African manufacturing firms. Journal of International Economics, 67(2), 373-391. http://dx.doi.org/10.1016/j.jinteco.2004.12.002

Vu, H., Lim, S., Holmes, M., \& Doan, T. (2013). Firm exporting and employee Benefits: First evidence from Vietnam manufacturing SMEs. Economics Bulletin, 33(1), 519-535.

Wagner, J. (2001). A note on the firm size - Export relationship. Small Business Economics, 17(4), 229-237. http://dx.doi.org/10.1023/a:1012202405889

Wooldridge, J. M. (2002). Econometric analysis of cross section and panel data. Cambridge, MA: The MIT press.

World Bank [WB]. (2012). Well begun, not yet done: Vietnam's remarkable progress on poverty reduction and the emerging challenges.

\section{Notes}

Note 1. Statistical yearbook (various issues) from Vietnam General Statistical Office.

Note 2. Statistical yearbook (various issues) from the Vietnamese General Statistical Office

Note 3. However, it is noted that Hanoi and Hatay is merged in 2008.

\section{Copyrights}

Copyright for this article is retained by the author(s), with first publication rights granted to the journal.

This is an open-access article distributed under the terms and conditions of the Creative Commons Attribution license (http://creativecommons.org/licenses/by/3.0/). 